\title{
The effect of creative writing activities on elementary school students' creative writing achievement, writing attitude and motivation*
}

\author{
Gökçen Göçen ${ }^{a} \dagger$ \\ ${ }^{a}$ Fatih Sultan Mehmet Vaku Üniversitesi, İstanbul, Turkey
}

\section{APA Citation:}

Göçen, G. (2019). The effect of creative writing activities on elementary school students' creative writing achievement, writing attitude and motivation. Journal of Language and Linguistic Studies, 15(3), 1032-1044.

Submission Date:29/06/2019

Acceptance Date:17/08/2019

\begin{abstract}
Writing skills have a tendency to lose their importance day by day. In addition, writing studies with a productbased approach discourage students from writing. In teaching mother tongue, creative writing activities, considered as process-based writing approach, are among the ones that will make students feel like writing and regard writing as a need. Writing, reviewing, and sharing the stages of the process-based writing approach are included in the Turkish Course Curriculum (MEB, 2018) starting from the $1^{\text {st }}$ grade. This study aims to examine the effects of creative writing activities on native Turkish-speaking students' creative writing achievement, writing attitudes and motivation in learning their mother tongue. The study employed one-group pretest-posttest experimental design. The sample of the study was formed by a total of 630 students from first, second, third and fourth grades. The data collection tools are "Written Production Instruction" (Türkel, 2011), "Writing Attitude Scale" (Yıldız \& Kaman, 2016), "The Scale of Writing Attitude" (Susar Kırmız1, 2009) and "Writing Motivation Scale" (Canıtezer, 2014). Arithmetic mean, standard deviation and t-test results and "Evaluation Criteria Form for Creative Writing" (Susar Kırmız1, 2008) were used in order for the analysis of the data. The results revealed that creative writing activities have a positive effect on students' creative writing achievement, writing attitude and motivation.
\end{abstract}

(C) 2019 JLLS and the Authors - Published by JLLS.

Keywords: Teaching writing; creative writing; writing achievement; writing attitude; writing motivation

\section{Introduction}

Nowadays, writing skills have started to be used less due to developing technologies. It is necessary to emphasize writing skills, so it will not be forgotten but improved. Writing is defined by Raimes (1983) as the communication of ideas clearly, fluently, and effectively and the transfer of emotions, thoughts, wishes and dreams by using symbols in an effective way in accordance with the grammar rules. The process of writing is a problem-solving process (Bereiter \& Scardamalia, 1987; Chen \& Zhou, 2010;

\footnotetext{
* This study includes some of the results of the project titled "Yazdıkça Yazıyorum" and coded 118B232, sponsored by TÜBİTAK 4004 Nature and Science Schools Project.

${ }^{\dagger}$ Gökçen Göçen. Tel.: +9-212-521-8100

E-mail address: ggocen@fsm.edu.tr
} 
Flower \& Hayes, 1980). This process of writing as complex problem solving is composed of planning, translation, reviewing stages (Flower \& Hayes, 1980).

Writing is a skill that develops later, harder and slower than speaking, listening and reading skills (Albertson \& Billingsley, 2000; Bayat, 2014; Demir, 2011; Karatay, 2011; Olinghouse \& Santangelo, 2010; Temizkan \& Yalçınkaya, 2013; Şahin, 2016). Bruning and Horn (2000) stated that students might develop negative attitudes towards writing and as a result acquire unproductive writing habits since writing is regarded as a complex activity and students generally have discouraging experiences with writing. Due to the same reason, writing is an activity that students are tired of, have difficulty with, feel reluctant about and dislike (Akkaya, 2011; Bayat, 2014; Kurudayığlu \& Karadağ, 2010). The reason why writing is perceived as a difficult skill is closely related to the importance that teachers attach to writing skills and how writing activities are conducted in the classroom (Göçen, 2018b). It is not possible to make students like writing and encourage them to write by setting strict rules in writing, by focusing on legible and neat sentences as well as the form and the cleanness of the paper. Emphasizing the rules of writing and grammar and having students write similar texts that explain proverbial statements would not help students fancy writing, as well (Oral, 2014; Susar Kırmız1, 2015; Tonyal1, 2010).

Şahbaz and Duran (2011) claimed that composition studies have been taken into account as the sole writing activity in classrooms; students got bored of writing and as a result produced similar writing products. In writing studies with a traditional understanding, the contents of the texts cannot be enriched, students cannot present original ideas and cannot involve themselves into their texts (Akkaya, 2011; Calp, 2013; Koçyiğit \& Sefer, 2005; Korkmaz, 2015; Zorbaz, 2010). These detract students from authenticity and result in uniform texts (Göçen, 2018a). Writing activities done in a traditional way cause writing skills to be out of favor, to be regarded as rare skills that few people can acquire and to bore and disincline students (Karatay, 2011; Kurudayığlu \& Karadağ, 2010; Oral, 2014; Susar Kırmız1, 2015). Because of insensitive writing studies, learners see writing as an activity that takes place only during the lessons, they escape from writing work and develop negative attitudes towards writing and as a result, they perceive writing as a skill that cannot be acquired (Demir, 2011; Korkmaz, 2015; Maltepe, 2006; Susar Kırmız1, 2009). Consequently, there is a serious problem with intrinsic motivation because students do not fancy and do writing activities (Dai, 2010).

For these reasons, it is important to follow current trends in writing, to apply innovations in the classroom, to create writing environments where students can write freely using their imagination, and to enable students to acquire writing skills that they can use throughout their lives (Okur \& Göçen, 2019). Therefore, it is necessary to place importance on teaching writing skills in schools in order to make students feel a need for writing.

There are creative writing activities that offer students opportunities like dreaming up, preparing content, expressing ideas and dreams freely, being active in writing process, having fun while writing and producing authentic content (Göçen, 2018b). Creative writing is considered as one of the most significant skills students can learn (Arthur \& Zell, 1990). There are numerous studies conducted by researchers concerning the impact of creative writing activities on students' attitudes towards writing, writing motivation and achievement. These studies usually cover a single grade and include a limited number of students. However, it is important that the students get acquainted with creative writing activities early in their school lives and it is important to study and analyze the effects of creative writing on students.

\subsection{Literature review}

Creative writing is writing about feelings, thoughts and impressions on the outside world by using imagination in an original, unusual, free and authentic way (Güleryüz, 2006; Küçük, 2007; Maltepe, 
2006; Oral, 2014; Temizkan, 2011; Topçuoğlu Ünal \& Sever, 2012; Yıldız, Okur, Ar1 \& Yılmaz, 2008). Mansoor (2010) defined creative writing as a way for writers to communicate their thoughts and feelings creatively in their own way. Şahbaz and Duran (2011) consider creative writing as a product of creative thinking and as a significant prerequisite. They believe that it needs to be authentic and fruitful in terms of expression and statement. Creative writing is about being original and imaginative rather than having correct thoughts and is the ability of using the language, but not transferring knowledge (Akdal \& Şahin, 2014).

Filbin (1963) stated that creative writing activities are not to be done for the sake of grammar, punctuation or spelling lessons. What is meant here is not the unnecessity of writing form or tools. He, on the contrary, suggested that making the final version of the original creative work more meaningful would help students develop these. Mansoor (2010) claimed that such definitions never attempted to limit creative writing to the accuracy in syntax and grammar. Arslan (2013) had a parallel claim and stated that when writing practices concentrate only on grammatically accurate text, they fail to reveal the initial function of writing, which is being a communicative tool.

A sound, stories, poems, plays, imaginative diaries, letters, dialogues, free writing from photographs and like are the technics that teachers may exploit in classrooms for creative writing pusposes (Durham, 1970). Creative writing activities help students reveal their creativity to write and produce as well as giving students ample chances to explore and understand value of writing (Essex, 1996; Gündüz \& Şimşek, 2016; Tompkins, 1982). Creative writing activities offer students chances to practice thinking, freedom of expression, design, creating a product, developing empathy, improving imagination, exploring different aspects of their lives and choosing writing topics and methods for themselves (Dai, 2010; Dev, Marwah \& Pal, 2009; Eliasova, 2001; Tok \& Kandemir, 2015; Tütüniş \& Küçükali, 2014; Weldon, 2009).

One of the most important goals of creative writing activities is enabling student to produce fluent, interesting as well as authentic written texts rather than boring and repetitive ones and to allow them to demonstrate their creative skills while writing. (Göçer, 2010; Maltepe, 2006; Temizkan, 2010). Other purposes of creative writing activities are to encourage learners to think, to improve their imagination while provoking their creativity, to uncover their own creative skills. Besides, creative writing activities aim to improve students' skills of self-knowledge, emotional self-regulation and thought regulation, decision and plan making skills as well as skills to implement these plans, to enable them to discover and to use information in a unique way (Aktaş \& Gündüz, 2004; Bağc1, 2011; Göçer, 2010; Gündüz \& Şimşek, 2016; Temizkan, 2010). For these reasons, teachers should attach utmost importance to creative writing activities (Akkaya, 2014).

Students' attitudes towards writing are formed at a young age and this attitude will probably be maintained in the future. This attitude of students will affect their motivation for writing and their success in writing. As Göçer (2014) mentioned, people's perspective and approach have a direct impact on how people use and demonstrate their skills in any job. As one of the most essential factors that directly affect and shape the writing skills is the attitude (Graham, 2006), students' writing skills are in close relationship with the frequency of writing activities as well as the way they are carried out.

The writing practices and writing experiences of the students affect them positively or negatively and lead them to adopt a positive or negative attitude to writing skills (Maltepe, 2006; Y1ldız \& Kaman, 2016). Since learners develop attitudes towards writing in elementary school years and the attitude will have a positive or negative impact on their learning in the future (Y1ldz \& Kaman, 2016), it is important to emphasize creative writing activities in schools so that student will develop sympathy for writing. It is not possible for a student who has a negative writing attitude to be successful in academic writing. Students' attitudes towards writing will also affect their future writing motivation. Writing motivation, 
just like writing attitude, affects academic writing achievement. Şahbaz and Duran (2011) stated that it is crucial to build up students' passion for writing so that their writing skills will improve. Pajares (1996) states that students who are not motivated enough to write are academically unsuccessful.

In the context of the problem in hand, it is important to measure the impact of creative writing activities conducted in the early years of schooling on students.

\subsection{Research questions}

The research question is "Do creative writing activities have an effect on writing skills, writing attitude and writing motivation of elementary school students studying their mother tongue?" This research aims to examine the effects of creative writing activities on students' creative writing achievement, writing attitudes and motivation. The study further intends to answer the following questions:

1. Do creative writing activities have an effect on students' writing achievement?

2. Do creative writing activities have an effect on students' writing attitude?

3. Do creative writing activities have an effect on students' writing motivation?

\section{Method}

One-group pretest-posttest experimental design was employed in the study. In this research model, the pre-test measurements of a single group are obtained and followed by a treatment as well as a posttest measurement of the same group. (Büyüköztürk, Kılıç Çakmak, Akgün, Karadeniz \& Demirel, 2016; Creswell, 2009).

The view of the research design employed in the present study is demonstrated in Table 1 below:

Table 1. View of research design

\begin{tabular}{ccc}
\hline Pre-test & Treatment & Post-test \\
\hline Written Production Instruction & & Written Production Instruction \\
Writing Attitude Scale & Implementation of Creative & Writing Attitude Scale \\
The Scale of Writing Attitude & writing activities & The Scale of Writing Attitude \\
Writing Motivation Scale & & Writing Motivation Scale \\
\hline
\end{tabular}

For this research, pre-test was carried out and followed by the implementation of 15 creative writing activities. After that, the same data collection tools were used again for post-test measurements.

\subsection{Sample / Participants}

For this study, elementary school teachers teaching 1st, 2nd, 3rd and 4th grades in 33 different schools were reached out to. Teachers volunteered to implement creative writing activities in their classrooms. Firstly, they conducted pre-tests on their students. After that, the treatment procedure which is the implementation of the creative writing activities followed. Then, teachers finalized the process with post-tests. 
The sample of study is formed by 630 students participated in all creative writing activities and completed both pre-tests and post-tests.

The list of schools where the participating students were studying is shared in the table below:

Table 2. The schools the participating students studied in

\begin{tabular}{lrrlrr}
\hline \multicolumn{1}{c}{ School } & Number of Students & & \multicolumn{2}{c}{ School } & Number of Students \\
\cline { 5 - 5 } Adnan Menderes İlkokulu & 24 & & Karadedeli İlkokulu & 20 \\
Alparslan İlkokulu & 7 & & Karaisalı Çukur İlkokulu & 8 \\
Azmi Ertuğrul ilkokulu & 31 & & Kartaltepe İlkokulu & 34 \\
Bahçelievler Gazi İlkokulu & 25 & & Konuksever İlkokulu & 47 \\
Barbaros İlkokulu & 18 & & Mustafa Kemal İlkokulu & 9 \\
Bekbele Fatih İlkokulu & 7 & & Nazife Hatun İlkokulu & 11 \\
Cumhuriyet İlkokulu & 22 & & Özdemir Gürocak İlkokulu & 23 \\
Dorukdibi İlkokulu & 5 & & Rahmiye İlkokulu & 15 \\
Duacılı Ahmet Güdücü İlkokulu & 11 & & Sancaktepe İlkokulu & 15 \\
Eskiizmir İlkokulu & 27 & & Sinan Göksun İlkokulu \\
Gazipaşa İlkokulu & 35 & & Şehit Serdar Gökbayrak İlkokulu & 12 \\
Halide Nusret Zorlutuna İlkokulu & 7 & & Toruntepe İlkokulu & 18 \\
Hanlı İlkokulu & 15 & & Türkan Sabancı İlkokulu & 8 \\
Hasan Tahsin İlkokulu & 48 & & Vali Mustafa Uygur İlkokulu \\
Hürriyet İlkokulu & 15 & Yavuz Selim İlkokulu & 7 \\
İsmet Paşa İlkokulu & 16 & Yılmaz Çebi İlkokulu & 36 \\
Karaağaç İlkokulu & 27 & Total & 6 \\
& & & & 21 & 630 \\
\hline
\end{tabular}

The distribution of participating students by gender and grade is shown in the following table:

Table 3. Distribution of participants based on gender and grade

\begin{tabular}{llll}
\hline Grade & Male & Female & Total \\
\hline $1^{\text {st }}$ Grade & 4 & 3 & 7 \\
$2^{\text {nd }}$ Grade & 21 & 18 & 39 \\
$3^{\text {rd }}$ Grade & 108 & 119 & 227 \\
$4^{\text {th }}$ Grade & 167 & 190 & 357 \\
Total & 300 & 330 & 630 \\
\hline
\end{tabular}


A total of 630 students studying their mother tongue at 1st, 2nd, 3rd and 4th grades formed the sample group of the study.

\subsection{Instrument(s)}

Various data collection tools suitable for the subquestions (research questions) were employed in the study:

1. What is the effect of creative writing on students' creative writing achievement?

In order to determine the impact of creative writing activities on students' creative writing achievement, the procedures that Türkel (2011) applied in his Ph.D. thesis for the very same purpose have been followed. To measure students' achievement on creative writing before the treatment, they were required to write a free-form text in their mother tongue about what the following instruction reminded them of: "If I were to be born again...". After the implementation of creative writing activities, the same instruction in their mother tongue was given to the students and the post-test process was carried out.

2. What is the effect of creative writing on students' writing attitude?

To measure the change in students' attitudes towards writing before and after the implementation of creative writing activities, the following scales were used as pre-tests and post-tests:

a. "Writing Attitude Scale", developed by Graham, Berninger and Fan (2007) and adapted to Turkish by Yildiz and Kaman (2016), was used. (The 5-item scale was unidimensional, the variance value for the whole scale was 53\% and the Cron-bach's Alpha value was found to be 0.77.)

b. "The Scale of Writing Attitude", developed by Susar Kirmız1 (2009), was used. (The scale was composed of 34 items. The items' factor eigenvalues were between 0.50 to 0.86. The Cronbach Alpha reliability coefficient was determined to be 0.90 .)

3. What is the effect of creative writing on students' writing motivation?

"Writing Motivation Scale", developed by Canitezer (2014), was used to measure the effect of creative writing activities on students' writing motivation. (Corrected item-total correlations of 24 items were above 0.30. Cronbach's Alpha value was 0.89.)

\subsection{Data collection procedures}

Prior to the implementation of creative writing activities in June 2018, teachers were informed about which creative writing activities to be done and how the activities would be implemented in a series of training sessions in June 2018. Between June 26 and July 1, 2018, 15 creative writing activities were conducted on teachers. Thus, teachers had a chance to have first-hand experience on creative writing activities. The teachers were then asked to do the same activities with their students in accordance with a specified schedule and procedure. Teachers were also provided with measurement tools for pre-tests and post-tests so that they will implement them before and after each activity.

Between September and December 2018, the teachers conducted 15 different creative writing activities as well as pre-tests and post-tests on their students.

The creative writing activities selected for the research are in line with the acquisition of writing skills in mother tongue in Turkish Course Curriculum (MEB, 2018). The following are the creative writing outcomes that are considered while planning creative writing activities. (MEB, 2018: 61-63):

- Does writing exercises $\left(1^{\text {st }}, 2^{\text {nd }}, 3^{\text {rd }}\right.$ and $4^{\text {th }}$ grades $)$

- Applies writing strategies $\left(1^{\text {st }}, 2^{\text {nd }}, 3^{\text {rd }}\right.$ and $4^{\text {th }}$ grades $)$ 
- Writes words and sentences about visuals $\left(1^{\text {st }}\right.$ grade $)$

- Supports written products with visual elements ( $1^{\text {st }}$ and $2^{\text {nd }}$ grades $)$

- Writes poems $\left(2^{\text {nd }}, 3^{\text {rd }}\right.$ and $4^{\text {th }}$ grades $)$

- Writes short texts (Diary, letter, memory) $\left(2^{\text {nd }}\right.$ and $3^{\text {rd }}$ grades $)$

- Uses illustrations and visuals to enrich his/her writing ( $3^{\text {rd }}$ grade)

- Writes by associating the events given in the visuals ( $3^{\text {rd }}$ grade)

- Writes narrative texts $\left(3^{\text {rd }}\right.$ and $4^{\text {th }}$ grades $)$

- Writes informative texts $\left(4^{\text {th }}\right.$ grade)

- Write short texts containing imaginary elements $\left(4^{\text {th }}\right.$ grade $)$

- Describes an event by associating the visuals $\left(4^{\text {th }}\right.$ grade $)$

- Uses drawings, graphics and visuals to enhance his/her writing ( $4^{\text {th }}$ grade)

The names and implementation dates of the creative writing activities conducted by the teachers are as follows:

Table 4. Creative writing activities conducted by the teachers

\begin{tabular}{|c|c|}
\hline Date & Creative Writing Activity and its Source \\
\hline \multirow{4}{*}{$\begin{array}{l}\text { September } \\
2018\end{array}$} & (Pre-Test Implementation) \\
\hline & Adım Adım Yazma (Step by Step Writing) (Göçen, 2018b) \\
\hline & Bir Ada Yaratıyorum (Creating an Island) (Ak, 2011; Göçen, 2018b) \\
\hline & Ayakkabılar ve Şapkalar (Writing from Objects) (Avc1, 2013; Bishop, 1990; Göçen, 2018b) \\
\hline \multirow{4}{*}{ October 2018} & $\begin{array}{l}\text { Farklı Devam Etseydi Ne Olurdu? (What Would Happen if Continued Differently?) (Göçen, } \\
\text { 2018b; Korkmaz, 2015) }\end{array}$ \\
\hline & $\begin{array}{l}\text { Kelime-Kavram Havuzundan Seçerek Yazma (Writing by Picking from a Word-Concept Pool) } \\
\text { (Göçen, 2018b; Korkmaz, 2015) }\end{array}$ \\
\hline & Kayıp İnsan (Missing Person) (Göçen, 2018b; Tonyalı, 2010) \\
\hline & Mektup Formları (Letter Forms) (Avc1, 2013; Bishop, 1990; Göçen, 2018b) \\
\hline \multirow{3}{*}{$\begin{array}{l}\text { November } \\
2018\end{array}$} & Kim, Nerede, Ne Yapmış (Who, Where, What) (Göçen, 2018b; Korkmaz, 2015) \\
\hline & $\begin{array}{l}\text { Penceremden Gördüklerim (What I See through my Window) (Göçen, 2018b; Korkmaz, } \\
\text { 2015)Pencere Problemi: Şiir Yazma (Window Problem: Poetry Writing) (Göçen, 2018b; Oral, } \\
\text { 2014) }\end{array}$ \\
\hline & $\begin{array}{l}\text { Rehberli Portreler (Guided Portraits-The Fifteen-Sentence Portrait) (Avc1, 2013; Bishop, } \\
\text { 1990; Göçen, 2018b) }\end{array}$ \\
\hline \multirow{5}{*}{$\begin{array}{l}\text { December, } \\
2018\end{array}$} & Zincir (The Chain) (Göçen, 2018b; Top, 2013) \\
\hline & Düşünce Kümeleri (Thought Clusters) (Göçen, 2018b; Öztürk, 2007) \\
\hline & Özgün Karakterler (Original Characters) (Göçen, 2018b; Öztürk, 2007) \\
\hline & Özel Mülkiyet Tekniği (Private Property Technique) (Göçen, 2018b; Peker, 2015) \\
\hline & (Post-Test Implementation) \\
\hline
\end{tabular}


For the present study, teachers first implemented the pre-tests. Then, the treatment consisting of 15 creative writing activities was followed by post-tests.

\subsection{Data analysis}

The collected data were processed under two main stages:

1. Written Production Instruction

In order to determine the effect of creative writing activities on students' creative writing achievement "Evaluation Criteria Form for Creative Writing", developed by Susar Kırmız1 (2008), was used for the evaluation of the texts created before and after the treatment. Below are the evaluation criteria that add up to 100 points (Susar Kirmızi, 2008):

Criterion 1: The text contains some new ideas that are not usual (20 points)

Criterion 2: An ordinary element is used/described in an extraordinary way (20 points)

Criterion 3: The text contains authentic similes (10 points)

Criterion 4: New ideas are expressed clearly (10 points)

Criterion 5: Feelings and ideas are expressed effectively and fluently (20 points)

Criterion 6: An appropriate title was used (10 points)

The texts produced by the students were first marked by the researcher and another faculty member. The averages of these two sets of scored were used as the final scores. The scores were analyzed on SPSS (ver. 21) software. Arithmetic mean and standard deviation were calculated, and dependent samples t-test was run for data analysis.

2. Writing Attitude Scale, The Scale of Writing Attitude, Writing Motivation Scale

The data collected via the pre-tests and the post-tests were transferred onto SPSS. After redefining the reverse items on the scales, arithmetic mean, standard deviation and dependent samples t-test results were obtained to analyze the data.

\section{Results}

In this section, the findings and comments about the data obtained under the research are presented under 3 headings based on the subquestions.

\subsection{Results on the effect of creative writing activities on students' creative writing achievement}

In order to reveal the effect of creative writing activities on the students' creative writing achievement, the texts that students produced as response to the pre-test and post-test were evaluated in accordance with the "Evaluation Criteria Form for Creative Writing" (Susar Kırmız1, 2008). Arithmetic mean and standard deviation of the scores were studied and dependent samples t-test results were obtained to see whether there was a statistically significant difference between the means of the pre-test and post-test. Obtained data can be seen in the table below:

Table 5. Comparison of pre-test and post-test measurements of students' creative writing achievement

\begin{tabular}{llllllll}
\hline Group & Test & $\mathrm{n}$ & $\mathrm{x}$ & $\mathrm{ss}$ & $\mathrm{sd}$ & $\mathrm{t}$ & $\mathrm{p}$ \\
\hline Students & Pre-test & 630 & 33.97 & 10.157 & \multirow{2}{*}{629} & --57.738 & $0,000 *$ \\
& Post-test & 630 & 51.58 & 9.525 & & & \\
\end{tabular}

$* \mathrm{p}<0,05$ 
Table 5 shows that students' average scores on the post-test $(\overline{\mathrm{x}}=51,58)$ are higher than the ones on the pre-test $(\overline{\mathrm{x}}=33,97)$. The t-test results showed a statistically significant difference between the two measurements $[\mathrm{t}(629)=-57,738 ; \mathrm{p}<0,05]$. Thus, it can be concluded that the creative writing activities have a positive effect on students' creative writing achievement.

\subsection{Results on the effect of creative writing activities on students' writing attitudes}

Two forms were used to measure students' attitudes towards writing. The mean and standard deviation of the data obtained from pre-tests and post-tests were analyzed. T-test was run to determine whether the difference between the mean scores was statistically significant.

The data obtained from the first form used to detect the effect of creative writing activities on students' attitude towards writing can be seen in the table below:

Table 6. Comparison of pre-test and post-test measures of students' writing attitude (1)

\begin{tabular}{cccccccc}
\hline Group & Test & $\mathrm{n}$ & $\overline{\mathrm{x}}$ & $\mathrm{ss}$ & $\mathrm{sd}$ & $\mathrm{t}$ & $\mathrm{p}$ \\
\hline Students & Pre-test & 630 & 2.7940 & .50058 & \multirow{2}{*}{629} & -50.979 & $0,000 *$ \\
& Post-test & 630 & 3.8463 & .15832 & & & \\
\hline
\end{tabular}

$* \mathrm{p}<0,05$

According to Table 6 , students' mean scores on the post-test $(\bar{x}=3,84)$ increased compared to the mean scores on the pre-test score $(\overline{\mathrm{x}}=2,79)$. The test results showed that the $\mathrm{p}$ value was significant at the level of $.05[t(629)=-50.979 ; \mathrm{p}<0,05]$. The results show that creative writing activities have a positive effect on elementary school students' attitude towards writing.

The data obtained from the second form used to determine the effect of creative writing activities on students' attitude to writing can be seen in the table below:

Table 7. Comparison of pre-test and post-test measures of students' writing attitude (2)

\begin{tabular}{cccccccc}
\hline \multicolumn{1}{c}{ Group } & Test & $\mathrm{n}$ & $\overline{\mathrm{x}}$ & $\mathrm{ss}$ & $\mathrm{sd}$ & $\mathrm{t}$ & $\mathrm{p}$ \\
\hline Students & Pre-test & 630 & 2.9423 & .43274 & \multirow{2}{*}{629} & -67.567 & $0,000 *$ \\
& Post-test & 630 & 4.4181 & .33992 & & & \\
\hline
\end{tabular}

$* \mathrm{p}<0,05$

According to Table 7, the mean score obtained from the post-tests $(\overline{\mathrm{x}}=4,41)$ increased compared to the mean score of the pre-tests $(\overline{\mathrm{x}}=2,94)$. The statistical analyses showed that the $\mathrm{p}$ value was significant at the level of $.05[\mathrm{t}(629)=-67.567 ; \mathrm{p}<0,05]$. The results show that creative writing activities have a positive effect on elementary school students' attitude towards writing.

\subsection{Results on the effect of creative writing activities on students' writing motivation}

In order to reveal the effect of creative writing activities on students' writing motivation, the mean score and standard deviation of the pre-test and post-test were calculated. Dependent samples t-test was run to determine whether the difference between the mean scores was statistically significant. 
The data obtained from the test used to understand the effect of creative writing activities on students' writing motivation can be seen in the table below:

Table 8. Comparison of pre-test and post-test measures of students' writing motivation

\begin{tabular}{cccccccc}
\hline Group & Test & $\mathrm{n}$ & $\overline{\mathrm{x}}$ & $\mathrm{ss}$ & $\mathrm{sd}$ & $\mathrm{t}$ & $\mathrm{p}$ \\
\hline Students & Pre-test & 630 & 2.7388 & .75065 & \multirow{2}{*}{629} & -56.732 & $0,000^{*}$ \\
& Post-test & 630 & 4.5469 & .22908 & & & \\
\hline
\end{tabular}

According to Table 8 , students' mean score on the post-tests $(\overline{\mathrm{x}}=4,54)$ increased when compared to the mean score of the pre-tests $(\overline{\mathrm{x}}=2,73)$. The $\mathrm{p}$ value was found to be significant at the level of .05 $[t(629)=-56.732 ; \mathrm{p}<0,05]$. The results show that creative writing activities have a positive effect on the motivation of elementary school students to write.

\section{Discussion and Conclusions}

Some studies concluded that students' attitudes towards writing are negative, they do not like writing and they get bored while writing. The fact that the structure of the writing and the writing product are overemphasized has an effect on such conclusions. (Göçen, 2018b).

The results produced by the present study showed that creative writing activities have a positive effect on students' creative writing achievement. There are different studies supporting the conclusion of this study (Ak, 2011; Beydemir, 2010; Conroy, Marchand \& Webster, 2009; Göçen, 2018b; İnal, 2006; Korkmaz, 2015; Memiş, Sever \& Bozkurt, 2016; Susar Kırmızı, 2015; Öztürk, 2007; Temizkan, 2011; Tok \& Kandemir, 2015; Top, 2013; Vass, 2007). Colantone, Cunnigham-Wetmore and Dreznes (1998), Tütüniş and Küçükali (2014) concluded that according to test results students' writing skills and language development improved upon the implementation of creative writing activities. Dai (2010), stated that creative writing activities improved students' language proficiency. The points where creative writing activities have a positive impact on students' language and writing skills are (İnal, 2006; Öztürk, 2007; Tonyal1, 2010): Progress in writing and punctuation skills in general, improvements in the use of grammar, paper layout, spelling rules, punctuation, text organization, as well as composition, focus on composition and fluency, development of the originality in writing, fluency of thoughts, word choice, sentence structure, having an authentic style and better expression of emotions.

Another result of the present study revealed a positive effect of creative writing activities on elementary school students' attitudes towards writing. There are also various studies supporting this (Ak, 2011; Bayat, 2016; Beydemir, 2010; Başkök, 2012; Bircan Manay, 2017; Göçen, 2018b; İnal, 2006; Korkmaz, 2015; Susar Kırmızı \& Beydemir, 2012; Öztürk, 2007; Top, 2013).

This study further concluded that creative writing activities have a positive effect on elementary school students' motivation to write. As Tompkins (2001) pointed out, developing creative writing skills means increasing intrinsic motivation. Creative writing activities enable students to form the topic of the text by themselves. This might be one of the reasons why creative writing activities improve students' motivation. In their study, Asser ve Poom-Valickis (2002) stated that allowing students to write on a topic of their choice increased their motivation towards writing. As process-oriented writing approach required, students included in this study were provided with ample chances to generate ideas through activities like brainstorming, drama and games. This is thought to have an influence on their writing motivation. Barry (1997) mentioned that it is necessary to let students do some thinking and 
provide them with opportunities to think so that they could generate ideas and get motivated. Prior to the creative writing activities conducted for this study, it was made sure that the students knew about the purpose of their writing and before some of the activities students were given multiple writing task options. These might also be among the reasons why students' writing motivation increased. Pierce, Plica, Ritt, Stanitz, \& Zinke (1997), stated that the lack of a purpose for writing decreased writing motivation. Codling, Gambrell, Kennedy, Plamer, \& Graham (1996), concluded that giving students a purpose to write and multiple writing task options to choose from may have a positive effect on their writing motivation.

Creative writing activities provide students with various chances to think creatively and help them improve their creative thinking skills as well as writing skills. Candar (2009) concluded that creative thinking technics have a positive effect on students' academic achievement, attitudes and motivation. Since the creative writing activities used in this study required students to think creatively, they had a positive effect on students' academic achievement, attitudes and motivation. While the creative writing activities included in this study were being conducted in classrooms, students were encouraged to write cooperatively by working in groups. This is also thought to have had an effect on students' achievement, attitudes and motivation. Aydin (2009) concluded that cooperative learning technics affect students' achievement, attitudes and motivation.

In conclusion, the present study revealed that creative writing activities have a positive effect on students' academic achievement on creative writing, their attitudes towards writing as well as writing motivation.

\section{Implications}

The fact that the mention of writing activities leads students to think of writing rules prevents students from developing motivation towards writing. Encouraging students and giving them reasons to feel motivated to write is of great importance. To this end, it is necessary to make students understand that writing activities are conducted so that they could learn how to express themselves and use their imagination rather than solely applying the writing rules. Therefore, some appealing creative writing activities that will make them feel entertained are to be employed.

Especially nowadays, it is important to conduct writing activities that will raise students' interest and improve their writing skills along with their creativity and imagination so that students will like writing and maintain their skills for written narration. (Göçen, 2018c). It is necessary to adopt a process-based writing approach and conduct creative writing activities in teaching mother tongue in order to enable students to advance their writing skills, develop positive attitudes towards writing and enjoy writing. Students begin to develop writing skills in their mother tongue in the $1^{\text {st }}$ grade. The expected outcomes related to writing skills stated in the Turkish Course Curriculum in mother tongue education reveals that students are expected to apply "writing strategies" starting from the $1^{\text {st }}$ grade. Turkish Course Curriculum does not clearly state the strategies that students are expected to gain in $1^{\text {st }}, 2^{\text {nd }}, 3^{\text {rd }}$ and $4^{\text {th }}$ grades. However, the present study revealed that the students were able to use the writing strategies (text completion, paraphrasing a text, writing as a group, guided writing, writing by selecting from a wordpool, writing the end of a text, creative writing, writing with the senses) related to creative writing mentioned in the curriculums for $5^{\text {th }}, 6^{\text {th }}, 7^{\text {th }}$ and $8^{\text {th }}$ graders. Applying these strategies related to creative writing starting from the $1^{\text {st }}$ grade of mother tongue education is recommended so that students' language and writing skills will improve. 


\section{References}

Ak, E. (2011). Yaratıcı yazma tekniklerinin ilköğretim 5. sınıf öğrencilerinin Türkçe dersindeki yazılı anlatım becerileri üzerindeki etkisi. Yayınlanmamış yüksek lisans tezi. Dokuz Eylül Üniversitesi, Eğitim Bilimleri Enstitüsü, İzmir.

Akdal, D., \& Şahin, A. (2014). The effects of intertextual reading approach on the development of creative writing skills. Eurasian Journal of Educational Research(54), 171-186.

Akkaya, N. (2011). İlköğretim 6. sınıf Türkçe dersinde yaratıcı yazma yaklaşımının Türkçe dersine yönelik tutuma etkisi. Buca Ĕ̈itim Fakültesi Dergisi, 311-319.

Akkaya, N. (2014). Sınıf öğretmenlerinin yaratıcı yazma sürecine ilişkin görüşlerinin değerlendirilmesi. Kuram ve Uygulamada Eğitim Bilimleri, 14(4), 1487-1504.

Aktaş, Ş., \& Gündüz, O. (2004). Yazılı ve sözlü anlatım kompozisyon sanatı. Ankara: Akçağ Yayınları.

Albertson, L. R., \& Billingsley, F. F. (2000). Using strategy instruction and self-regulation to improve gifted students' creative writing. Journal of Advanced Academics, 12(2), 90-101.

Arslan, R. C. (2013). An integrated approach to enhancing prospective English language teachers' writing skills. Journal of Language and Linguistic Studies, 9(2), 1-17.

Arthur, B., \& Zell, N. A. (1990). Strategy for teaching creative writing skills to emotionally disturbed students. Preventing School Failure, 34(4), 26-31.

Asser, H., \& Poom-Valickis, K. (2002). Learning to write: From choosing the topic to final draft. Journal of Educational Research, 1-10.

Avc1, A. S. (2013). Yaratıcı yazma etkinliklerinin 8. sinıf öğrencilerinin yazma eğilimleri ve yazma kaygılarına etkisi. Yayınlanmamış yüksek lisans tezi. Niğde Üniversitesi, Eğitim Bilimleri Enstitüsü, Niğde.

Aydın, F. (2009). İşbirlikli öğrenme yönteminin 10. sınıf coğrafya dersinde başarlya tutuma ve motivasyona etkileri. Yayınlanmamış doktora tezi. Gazi Üniversitesi, Eğitim Bilimleri Enstitüsü, Ankara.

Bağcı, H. (2011). Yazılı anlatım ve unsurları. M. Özbay (Ed.), Yazma eğitimi (pp. 85-124). Ankara: Pegem Akademi Yayınları.

Barry, B. A. (1997). Motivating students to write: Implementing creative theory to overcome the habitual and encourage autotelic flow. Journal of Educational Research, 1-12.

Başkök, B. (2012). İlköğretim yedinci sınıf öğrencilerinde uygulanan yaratıcı yazma çalışmalarının, ögrencilerin yaratıcllıklarına ve Türkçe dersine olan tutumlarına etkisinin incelenmesi. Yayınlanmamış yüksek lisans tezi. Akdeniz Üniversitesi, Sosyal Bilimler Enstitüsü, Antalya.

Bayat, N. (2014). Sürece dayalı yazma yaklaşımının yazma başarısı ve kaygısı üstündeki etkisi. Kuram ve Uygulamada Ë̆itim Bilimleri, 14(3), 1123-1141.

Bayat, S. (2016). The effectiveness of the creative writing instruction program based on speaking activities. International Electronic Journal of Elementary Education, 8(4), 617-628.

Bereiter, C., \& Scardamalia, M. (1987). The psychology of written composition. Hillsdale, NJ; London: Lawrence Erlbaum Associates. 
Beydemir, A. (2010). İlköğretim 5. sınıf Türkçe dersinde yaratıcı yazma yaklaşımının yazmaya yönelik tutumlara, yaratıcı yazma ve yazma erişisine etkisi. Yayınlanmamış yüksek lisans tezi. Pamukkale Üniversitesi, Sosyal Bilimler Enstitüsü, Denizli.

Bircan Manay, E. (2017). Kelime ă̆ı yönteminin ilköğretim 6. sınıf öğrencilerinin yazmaya karşı tutumlarına ve yazma özyeterlik algısına etkisi. Dokuz Eylül Üniversitesi, Eğitim Bilimleri Enstitüsü, İzmir.

Bishop, W. (1990). Released into language: Options for teaching creative writing. Illlinois: National Council Of Teachers Of English.

Bruning, R., \& Horn, C. (2000). Developing motivation to write. Educational Psychologist, 35(1), 2537.

Büyüköztürk, Ş., Kılıç Çakmak, E., Akgün, Ö. E., Karadeniz, Ş., \& Demirel, F. (2016). Bilimsel araştırma yöntemleri (22. Baskı). Ankara: Pegem Akademi Yayınları.

Calp, M. (2013). Serbest ve yaratıcı yazma tekniğine göre oluşturulan kompozisyonların yazılı anlatımın niteliği ve puanlama tekniği açısından karşılaştırılması. Turkish Studies - International Periodical For The Languages, Literature and History of Turkish or Turkic, 8(9), 879-898.

Candar, H. (2009). Fen eğitiminde yaratıcı düşünme öğretim tekniklerinin öğrencilerin akademik başarı tutum ve motivasyonlarına etkisi. Yayınlanmamış yüksek lisans tezi. Marmara Üniversitesi, Eğitim Bilimleri Enstitüsü, İstanbul.

Canıtezer, A. (2014). 8. sınıf öğrencilerinin yazma motivasyonu ile yazılı anlatım beceri düzeyleri üzerine bir araştırma. Yayınlanmamış doktora tezi. Necmettin Erbakan Üniversitesi Eğitim Bilimleri Enstitüsü, Konya.

Chen, S., \& Zhou, J. (2010). Creative writing strategies of young children: Evidence from a study of Chinese emergent writing. Thinking Skills and Creativity, 5(3), 138-149.

Codling, R. M., Gambrell, L. B., Kennedy, A., Plamer, B. M., \& Graham, M. (1996). The teacher, the text and the context: Factors that influence elementary students motivation to write. Journal of Educational Research, 1-68.

Colantone, L., Cunnigham-Wetmore, M., \& Dreznes, J. (1998). Improving creative writing. Masters Theses, Saint Xavier University, Chicago.

Conroy, M., Marchand, T., \& Webster, M. (2009). Motivating primary students to write using writer's workshop. Online Submission, Master of Arts Action Research Project, Saint Xavier University., http://www.eric.ed.gov/ ED504817.

Creswell, J., W. (2009). Research design: Qualitative, quantitative, and mixed methods approaches. Los Angeles: SAGE.

Dai, F. (2010). English language creative writing in mainland China. World Englishes, 29(4), 546-556.

Demir, T. (2011). İlköğretim ögrencilerinin yaratıcı yazma becerileri ile yazma özyeterlik algısı ve başarı amaç yönelimi türleri iliş̧kisinin değerlendirilmesi. Yayınlanmamış doktora tezi. Gazi Üniversitesi, Eğitim Bilimleri Enstitüsü, Ankara.

Dev, A. N., Marwah, A., \& Pal, S. (2009). Creative writing: A beginner's manual. India: Pearson Longman.

Durham, M. K. (1970). Creative writing. English Studies in Africa, 13(1), 155-174. 
Eliasova, V. (2001). Literature and creative writing projects. Revista de Filología y su Didáctica, 23, 473-480.

Essex, C. (1996). Teaching creative writing in the elementary school. ERIC Digest, 1-6.

Filbin, R. L. (1963). Teaching creative writing in the elementary school. Elementary English, 40(1), 4345.

Flower, L. S., \& Hayes, J. R. (1980). The dynamics of composing: Making plans, juggling constraints. L. W. Gregg, \& E. R. Steinberg (Ed.), Cognitive processes in writing (pp. 31-50). Hillsdale, NJ: Lawrence Erlbaum.

Göçen, G. (2018a). Öğretmenlerin yaratıcı yazma tekniklerine yönelik değerlendirmeleri: Bir eylem araştırması. OPUS-Uluslararası Toplum Araştırmaları Dergisi, 9(16), 625-677.

Göçen, G. (2018b). Sınıf öğretmenlerinin yazmaya yönelik yeterlilik algısına, tutumuna ve yaratıcı yazma başarısına yaratıcı yazma çalışmalarının etkisi. Turkish Studies - International Periodical For The Languages, Literature and History of Turkish or Turkic, 13(27), 737-762.

Göçen, G. (2018c). Sınıf öğretmenlerinin yaratıcı yazma uygulamalarına yönelik öz değerlendirmeleri. Diyalektolog Ulusal Sosyal Bilimler Dergisi(19), 469-502.

Göçer, A. (2010). Türkçe eğitiminde yazma eğitimi. Uluslararası Sosyal Araştırmalar Dergisi, 3(12), 179-195.

Göçer, A. (2014). Yazma Tutum Ölçeği'nin (YTÖ) Türkçeye uyarlanması: Geçerlik ve güvenirlik çalışması. Kastamonu Eğitim Dergisi, 22(2), 515-524.

Graham, S. (2006). Writing. P. Alexander, \& P. Winne (Ed.), Handbook of educational psychology. Mahwah, NJ: Erlbaum.

Güleryüz, H. (2006). Yaratıcı çocuk edebiyatı. Ankara: Pegem Akademi Yayınları.

Gündüz, O., \& Şimşek, T. (2016). Anlatma teknikleri 2 Uygulamalı yazma eğitimi el kitabı. Ankara: Grafiker Yayınları.

İnal, S. (2006). Yabancı dil öğretimindeki hedeflerin gerçekleştirilmesinde "Clustering" yazllı anlatım tekniğinin ögrenci tutumu ve başarısı üzerindeki etkileri. Yayınlanmamış doktora tezi. Dokuz Eylül Üniversitesi, Eğitim Bilimleri Enstitüsü, İzmir.

Karatay, H. (2011). 4+1 planlı yazma ve değerlendirme modelinin öğretmen adaylarının yazılı anlatım tutumlarını ve yazma becerilerini geliştirmeye etkisi. Turkish Studies International Periodical for the Languages, Literature and History of Turkish or Turkic, 6(3), 1029-1047.

Koçyiğit, B. K., \& Sefer, G. D. (2005). Süreç değerlendirme yaklaşımlarıyla yazma becerilerinin gelişstirilmesine yönelik bir çalışma: Benim öykülerim. Eğitimde İyi Örnekler Konferansı, Sabanc1 Üniversitesi, İstanbul.

Korkmaz, G. (2015). Yaratıcı yazma yönteminin 6. sinıf ögrencilerinin yazma öz yeterlik algılarına, yazmaya ilişkin tutumlarına ve yazma becerisi akademik başarllarına etkisi. Yayınlanmamış yüksek lisans tezi. Gaziantep Üniversitesi, Eğitim Bilimleri Enstitüsü, Gaziantep.

Kurudayığlu, Ö., \& Karadağ, Ö. (2010). İlköğretim öğrencilerinin yazılı anlatımlarının konu seçimleri açısından incelenmesi. Mustafa Kemal Üniversitesi Sosyal Bilimler Enstitüsü Dergisi, 7(13), $192-$ 207.

Küçük, S. (2007). Yazılı anlatım ve yaratıcılık. Samsun: Ondokuz Mayıs Üniversitesi Yayınları. 
Maltepe, S. (2006). Yaratıcı yazma yaklaşımı açısından Türkçe derslerindeki yazma süreçlerinin ve ürünlerinin değerlendirilmesi. Yayınlanmamış doktora tezi. Ankara Üniversitesi Sosyal Bilimler Enstitüsü, Ankara.

MEB Komisyon (2018). Türkçe dersi ögretim programı (Illkokul ve ortaokul 1, 2, 3, 4, 5, 6, 7 ve 8. siniflar). Ankara: MEB.

Mansoor, A. (2010). Teaching creative writing to university level second language learners in Pakistan. New Writing: The International Journal for the Practice and Theory of Creative Writing, 7(3), 201218.

Memiş, A., Sever, E., \& Bozkurt, M. (2016). Yaratıcı yazma ve yaratıcı drama yaklaşımının ilkokul öğrencilerinin yaratıcı yazma becerilerine ve yardımseverlik tutumlarına etkisi. Turkish Studies International Periodical for the Languages, Literature and History of Turkish or Turkic, 11(3), 1685-1702.

Okur, A., \& Göçen, G. (2019). Türkçe öğretiminde güncel eğilimler ve sorunlar. F. Topçuoğlu Ünal (Ed.), Türkçe Öğrenme ve Öğretim Yaklaşımları (pp. 235-260). Ankara: Nobel Yaynları.

Olinghouse, N. G., \& Santangelo, T. (2010). Assessing the writing of struggling learners. Focus On Exceptional Children, 43(4), 1-27.

Oral, G. (2014). Yine yazı yazıyoruz (5. Basım). Ankara: Pegem Akademi Yayınları.

Öztürk, E. (2007). İlköğretim V. sınıf ögrencilerinin yaratıcı yazma becerilerinin değerlendirilmesi. Yayınlanmamış doktora tezi. Gazi Üniversitesi, Eğitim Bilimleri Enstitüsü, Ankara.

Pajares, F. (1996). Self-efficacy beliefs in academic settings. Review of Educational Research, 66, 543578.

Peker, Ş. (2015). Yazılı anlatım becerilerinin gelişstirilmesinde yaratıcı drama tekniklerinden özel mülkiyet tekniğinin yaratıcı yazma yaklaşımı ile karşılaş̧ırılması. Yayınlanmamış yüksek lisans tezi. Ankara Üniversitesi, Eğitim Bilimleri Enstitüsü, Ankara.

Pierce, J., Plica, C., Ritt, J., Stanitz, K., \& Zinke, C. (1997). Motivating reluctant writers. Journal of Educational Research, 1-71.

Raimes, A. (1983). Techniques in teaching writing. Oxford: Oxford University Press.

Susar Kırmızı, F. (2008). Türkçe dersinde yaratıcı drama yönteminin yaratıcı yazma başarısına etkisi ve yazılı anlatım ürünlerinin değerlendirilmesi. Ankara Üniversitesi Eğitim Bilimleri Dergisi, 41 (Özel Say1), 251-275.

Susar Kırmızı, F. (2009). Türkçe dersinde yaratıcı drama yöntemiyle yaratıcı yazma çalışmalarının yazmaya yönelik tutuma etkisi. Yaratıcı Drama Dergisi, 4(7), 51-68.

Susar Kırmızı, F. (2015). Yaratıcı drama ve yaratıcı yazma uygulamalarının yaratıcı yazma başarısına etkisi. Ĕgitim ve Bilim, 40(181), 93-115.

Susar Kırmızı, F., \& Beydemir, A. (2012). İlköğretim 5. sınıf Türkçe dersinde yaratıcı yazma yaklaşımının yazmaya yönelik tutumlara etkisi. Ahi Evran Üniversitesi Kırşehir Eğitim Fakültesi Dergisi (KEFAD), 13(3), 319-337.

Şahbaz, N. K., \& Duran, G. (2011). The efficiency of cluster method in improving the creative writing skill of 6th grade students of primary school. Educational Research and Reviews, 6(11), 702-709.

Şahin, A. (2016). Yaratıcı yazma. F. Susar Kırmızı (Ed.), Illk ve ortaokullarda Türkçe öğretimi (pp. 273308). Ankara: An1 Yayınc1lık. 
Temizkan, M. (2010). Türkçe öğretiminde yaratıcı yazma becerilerinin geliştirilmesi. Türklük Bilimi Araştırmaları Dergisi(27), 621-643.

Temizkan, M. (2011). Yaratıcı yazma etkinliklerinin öykü yazma becerisi üzerindeki etkisi. Kuram ve Uygulamada Ĕ̈itim Bilimleri, 11(2), 919-940.

Temizkan, M., \& Yalçınkaya, M. (2013). İlköğretim 6. 7. 8. sınıf Türkçe öğretmenlerinin yaratıcı yazma etkinliklerini uygulama durumları. Dicle Üniversitesi Ziya Gökalp Eğitim Fakültesi Dergisi(20), 7091.

Tok, Ş., \& Kandemir, A. (2015). Effects of creative writing activities on students' achievement in writing, writing dispositions and attitude to English. Procedia - Social and Behavioral Sciences(174), 1635-1642.

Tompkins, G. E. (1982). Seven reasons why children should write stories. Language Arts, 59(7), 718 721.

Tompkins, G. E. (2001). Literacy for the 21 st century. Upper Saddle River, NJ: Prentice Hall.

Tonyalı, E. (2010). Yaratıcı yazma uygulamalarının ilköğretim ilköğretim altıncı sinıf öğrencilerinin yazma becerilerine etkisi. Yayınlanmamış yüksek lisans tezi. Abant İzzet Baysal Üniversitesi, Sosyal Bilimler Enstitüsü, Bolu.

Top, F. (2013). Yabancı dil olarak Türkçe ögrretiminde yaratıcı yazma tekniklerinin kullanılması. Yayınlanmamış yüksek lisans tezi. Dokuz Eylül Üniversitesi, Eğitim Bilimleri Enstitüsü, İzmir.

Topçuoğlu Ünal, F., \& Sever, A. (2012). Yaratıcı yazmada müziğin etkisi. Turkish Studies International Periodical For The Languages, Literature and History of Turkish or Turkic, 7(4), 2907-2918.

Türkel, A. (2011). Yaratıcı dramanın yaratıcı yazma başarısına ve yazmaya karşı tutuma etkisi (İlköğretim 8. sınıf örneği). Yayınlanmamış doktora tezi. Dokuz Eylül Üniversitesi, Eğitim Bilimleri Enstitüsü, İzmir.

Tütüniş, B., \& Küçükali, S. (2014). The impact of creative writing on foreign language (English) proficiency development. International Online Journal of Education and Teaching, 1(2), 82-89.

Vass, E. (2007). Exploring processes of collaborative creativity. The role of emotions in children's joint creative writing. Thinking Skills and Creativity, 107-117.

Weldon, F. (2009). On assessing creative writing. New Writing, 6(3), 168 -174.

Yıldız, C., Okur, A., Arı, G., \& Yılmaz, Y. (2008). Kuramdan uygulamaya Türkçe öğretimi. Ankara: Pegem Akademi Yayınları.

Yıldız, M., \& Kaman, Ş. (2016). İlköğretim (2-6.) sınıf öğrencilerinin okuma ve yazma tutumlarının incelenmesi. Türkiye Sosyal Araşttrmalar Dergisi(2), 507-522.

Zorbaz, K. Z. (2010). İlköğretim okulu öğrencilerinin yazma kaygı ve tutukluğunun yazıl anlatım becerileriyle ilişkisi. Yayınlanmamış doktora tezi. Gazi Üniversitesi, Eğitim Bilimleri Enstitüsü, Ankara. 


\section{Yaratıcı yazma çalışmalarının ilkokul öğrencilerinin yaratıcı yazma başarısına, yazmaya yönelik tutumuna ve motivasyonuna etkisi}

\section{$\ddot{O} \mathbf{z}$}

Günümüzde yazma becerisi giderek önemini kaybetmektedir. Ürün temelli bir yaklaşımla yapılan yazma çalışmaları da öğrencileri yazmaktan uzaklaştırmaktadır. Ana dili eğitiminde, öğrencilere yazmayı sevdirecek, yazmanın bir ihtiyaç olduğunu hissettirecek çalışmalar arasında süreç temelli yazma yaklaşımlarından biri olan yaratıcı yazma çalışmaları bulunmaktadır. Süreç temelli yazma yaklaşımının aşamalarını içeren yazma çalışmaları yapma, yazdıklarını gözden geçirme ve yazdıklarını paylaşma 1. sınıftan itibaren Türkçe Dersi Öğretim Programı'nda (MEB, 2018) yer almaktadır. Bu çalışmada, yaratıcı yazma çalışmalarının ana dili Türkçe olan öğrencilerin ana dili eğitimlerinde yaratıcı yazma başarısına, yazmaya yönelik tutumuna ve motivasyonuna etkisini incelemek amaçlanmıştır. Araştırmada deneysel desenlerden tek gruplu öntest-sontest deney deseni kullanılmıştır. Araştırma kapsamında 1., 2., 3. ve 4. sınıfta okuyan toplam 630 öğrenci çalışmanın örneklemini oluşturmuştur. Araştırmada veri toplama aracı olarak, Yazılı Ürün Elde Etme Sorusu, Yazma Tutumu Ölçeği (Yıldız \& Kaman, 2016), Yazmaya Yönelik Tutum Ölçeği (Susar Kırmızı, 2009), Yazma Motivasyonu Ölçeği (Canıtezer, 2014) kullanılmışırı. Verilerin çözümlenmesi için aritmetik ortalama, standart sapma ve (bağımlı örneklem) t-testi istatistik teknikleri ve Yaratıcı Yazma İçin Değerlendirme Ölçütleri Formu (Susar Kırmızı, 2008) kullanılmıştır. Çalışma sonucunda, yaratıcı yazma çalışmalarının öğrencilerin yaratıcı yazma başarısı, yazma tutumu ve motivasyonu üzerinde olumlu etkisinin olduğu görülmektedir.

Anahtar sözcükler: Yazma eğitimi; yaratıcı yazma; yazma başarısı; yazma tutumu; yazma motivasyonu

\section{AUTHOR BIODATA}

Having graduated from the department of Turkish Language and Literature at Çanakkale Onsekiz Mart University in 2008, Göçen completed her MA and Ph.D. studies in Turkish Language Teaching at Sakarya University in 2011 and 2016, respectively. She taught Turkish as a foreign language at İstanbul University before completing her Ph.D studies. In 2016, the researcher started working as an assistant professor in the department of Turkish Language Teaching at Fatih Sultan Mehmet Vakıf University, where she is currently working. Göçen focuses on teaching Turkish as a native language as well as Turkish as a foreign language. 